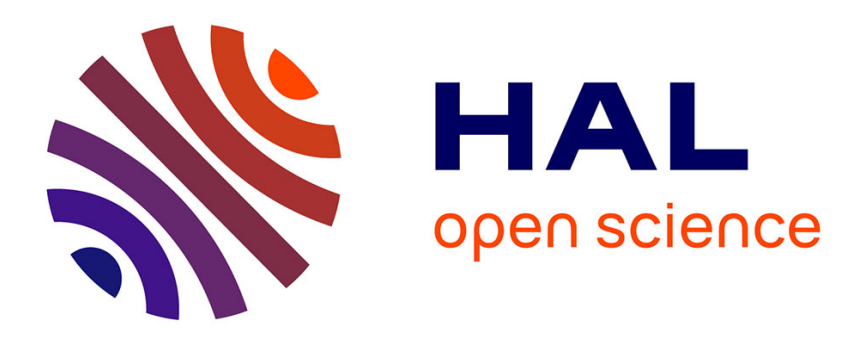

\title{
A survey of weeds that are increasingly spreading in Europe
}

\author{
Ewald Weber, Daniel Gut
}

\section{To cite this version:}

Ewald Weber, Daniel Gut. A survey of weeds that are increasingly spreading in Europe. Agronomy for Sustainable Development, 2005, 25 (1), pp.109-121. hal-00886262

\section{HAL Id: hal-00886262 \\ https://hal.science/hal-00886262}

Submitted on 1 Jan 2005

HAL is a multi-disciplinary open access archive for the deposit and dissemination of scientific research documents, whether they are published or not. The documents may come from teaching and research institutions in France or abroad, or from public or private research centers.
L'archive ouverte pluridisciplinaire HAL, est destinée au dépôt et à la diffusion de documents scientifiques de niveau recherche, publiés ou non, émanant des établissements d'enseignement et de recherche français ou étrangers, des laboratoires publics ou privés. 


\title{
A survey of weeds that are increasingly spreading in Europe
}

\author{
Ewald WEBER ${ }^{\mathrm{a}, \mathrm{b} *}$, Daniel GUT ${ }^{\mathrm{a}}$ \\ ${ }^{a}$ Swiss Federal Research Station of Fruit-Growing, Viticulture and Horticulture, 8820 Wädenswil, Switzerland \\ ${ }^{\mathrm{b}}$ Swiss Federal Institute of Technology, Geobotanical Institute, Zürichbergstrasee 38, 8044 Zurich, Switzerland
}

(Received 19 September 2003; accepted 11 October 2004)

\begin{abstract}
A Europe-wide survey was conducted by sending questionnaires to weed scientists in order to evaluate currently troublesome weeds and those which may cause problems in the future. Recipients were asked to list species that are spreading and cause problems in agroecosystems, and to rate these according to three scores (degree of weediness, degree of spread potential, and degree of control success), with three levels for each score (low, medium and high). In total, 281 species were reported from 26 European countries. Most of them were annuals (48\%), followed by perennials (34\%) and biennials (14\%). There were significant differences in weed scores among these life forms. Weed scores were unrelated to each other, implying that they have different meanings with respect to the biology of the species. Weed scores did not correlate with European range size, implying that they indicate the weediness of the species independently of the geographical distribution and can be used to prioritize weed species for management.
\end{abstract}

noxious weed lists / risk assessment / surveys / weediness / weed control

\section{INTRODUCTION}

The increasing number of non-native plant species in most regions is a major component of global change [26] and includes both the spread of exotic species into natural environments and the spread of weeds in agroecosystems. Weed communities of arable land may change rapidly over time and vary among different regions. Within the last few decades, a general decline in weed species has been observed in parts of Europe, mostly as a result of increased fertilization and effective control $[1,4]$. This decline has mostly affected species of arable land that are a valuable component of biodiversity, some native weeds being endangered species and thus having a high conservation value $[15,25]$. However, it has also been observed that certain species are increasing in abundance, including species that are difficult to control and causing extensive weed problems [1]. For any country, new plant species may originate by naturalization of intentionally introduced species, by the onset of the spread of already present species, by natural immigration of species that expand their range, or by unintentional introduction of species from abroad. The latter include species from other continents and from other countries on the same continent.

Changes in the composition of weed floras are associated with many factors and their interactions, including ecological traits of the species involved and the recipient habitats, and patterns of land-use change. Among the factors that may promote the establishment of new weed species are the evolution of her- bicide resistance [23], increasing extensivation and extension of late spring-seeded field crops [2], reduction of early-emerging weeds due to herbicide control, favoring late-emerging and competitively strong weeds [22], and climatic change, leading to the range expansion of weeds from warmer climates [18]. In Germany, the observed changes in the weed flora during the last few decades were attributed to changes in arable farming practice, including fertilizing, the use of more competitive crops, enhanced weed control, modifications in sowing technique, and purification of seed [1].

Climate change, land-use change, and the increasing international trade is likely increasing the number of new weed species in European countries. An important objective of noxious weed management is to reduce the spread of serious weeds and to prevent their introduction from adjacent geographic areas. Weeds are dispersed by various agents, but human activity is probably the most important one [17]. Therefore, it is essential to assess which weed species are problematic and to set priorities with regard to developing weed management strategies. In order to prevent new weed problems, the following steps are necessary [28, 30]: (1) identification of foreign weeds that could cause problems by performing weed risk assessments, (2) early detection of infestations if the species is already established, (3) assessment of the invader's noxious potential, and (4) implementation of the necessary measures to control or eradicate new weed species. Performing a weed risk assessment is common practice, for example, in New Zealand or Australia $[3,8,16]$.

\footnotetext{
* Corresponding author: ewald.weber@env.ethz.ch
} 
In this paper, we present the results of a Europe-wide survey of troublesome weed species in various agroecosystems. Our aim was to evaluate currently problematic weed species or those that could potentially cause new weed problems within arable lands of Europe, and to assess their weediness. The questions addressed were: (1) what are the most important current weed species in European agroecosystems? (2) how are these species rated by weed scientists? (3) how is the rating of the weeds related to their distribution?

\section{MATERIALS AND METHODS}

\subsection{Weed survey}

We conducted a Europe-wide survey by sending form sheets to leading weed scientists. Recipients were asked to provide species lists of weeds (1) that either generally show a tendency of increasing spread, or (2) have showed a rapid increase in infested areas within the last 20 years, (3) that are causing problems in agricultural habitats, or (4) species that have been present for a long time but recently have begun to spread, or (5) recently introduced and spreading species. In addition, recipients were asked to indicate the occurrence (presence/absence) of each of the species in the following agroecosystems: (1) fodder plants and pastures, (2) cereals, (3) grain legumes, (4) root crops, (5) vegetables and ornamentals, (6) orchards, (7) vineyards, and (8) other agricultural areas. The above definitions for the agroecosystems may differ from crop systems defined by weed scientists, but for the present large-scale survey, the form sheet was kept as simple as possible.

Each species could be rated by the recipients at three levels (low, medium and high) for three scores, representing different aspects of the biology of the weed and its control: (1) potential for further spread, (2) weediness (local abundance), and (3) success of control. For the sake of simplicity, no a priori distinctions for each agroecosystem were made. For the purpose of this study, the information that could be obtained is sufficient.

A database was created comprising all listed weed species with their respective occurrences in the agroecosystems and countries. We screened species for synonyms and tabulated them according to subsequent analyses. For a general description, the life forms and families were identified for each species. The range size in Europe was added to each species, and range size was expressed as the number of European countries where the species occurs. These data were taken from the Flora Europaea database (URL: http://rbg-web2.rbge.org.uk/FE/fe.html).

\subsection{Rating of species}

For each species, the scores provided by the weed scientists were averaged in order to obtain a general rating for "spread potential", "weediness", and "control success", respectively. We then ranked the species according to the first two weed scores and listed the species with the highest rankings for each of the crop systems. The ranking was done as follows: first, species were ranked according to "spread potential". Within the highest values of this score, species were ranked according to "weediness". The fifteen species with the highest ranking were defined as the most troublesome weeds. The score for "control success" was not considered at this point since it reflects a different aspect of weediness, e.g. how easy a species is to control, but also the availability of control methods and the efforts put into weed control. The score for "control success" was used for subsequent analyses.

\subsection{Relationships between distribution and weed scores}

We used regression analyses in order to investigate the relationships among the three weed scores and between weed scores and geographic distribution. This shows, for example, whether species rated as serious weeds were also among the most widespread ones. Analysis of variance was used to test for differences in weed scores and geographic distribution among life forms.

\section{RESULTS}

\subsection{Number of weed species}

In total, 281 weed species were reported, comprising 176 genera and 48 families (Appendix 1). The absolute number of species for individual countries varied considerably, ranging from 5 to 100 . The mean number of species per crop system ranged from 1.4 to 12.5 (Tab. I), and high values were apparent in countries in Eastern Europe, e.g., Romania, Poland and Bulgaria (Tab. I).

The largest families were the Asteraceae (61 species), Poaceae (55), Brassicaceae (15), Polygonaceae (14) and Apiaceae (11). The most significant genera were Amaranthus, Bromus and Rumex with seven species each. The species:family ratio was 6.2 , the species:genera ratio 1.6.

Although many of the weeds were annuals, the species reported formed an ecologically diverse group comprising all life forms (Tab. II). Herbaceous perennials made up $32.5 \%$ of all species. The distribution of life forms among crop systems varied: annuals were predominant in cereals, perennials in cereals and orchards (Tab. III), although differences among crop systems were not pronounced. The number of weed species reported for different crop systems was rather high, with most weeds occurring in cereals, and vegetables and ornamentals (Tab. III).

\subsection{Variation of weed scores}

Most species obtained intermediate scores (Fig. 1), and the relative fraction of annuals and perennials, respectively, differed among classes of scores. There were more perennials with high scores for weediness than annuals. Perennials generally obtained low scores for control success (Fig. 1). The three life forms, annuals, biennials and perennials, differed significantly with respect to the mean score for spread potential and the mean score for control success (Tab. IV). There were no differences in the number of countries for which the species was listed, and for European range size (Tab. IV).

Pronounced differences in scores were apparent among crop systems, as well as among life forms (Fig. 2). Generally, weeds 
Table I. Number of weed species with a high spread potential reported for 26 European countries in a questionnaire.

\begin{tabular}{|c|c|c|}
\hline & $\begin{array}{c}\text { Species } \\
\text { per country }\end{array}$ & $\begin{array}{l}\text { Mean No. of species } \\
\text { per crop system }\end{array}$ \\
\hline \multicolumn{3}{|l|}{ Country } \\
\hline Albania & 42 & 6.0 \\
\hline Austria & 21 & 5.3 \\
\hline British Isles & 28 & 3.5 \\
\hline Bulgaria & 44 & 6.3 \\
\hline Czech Republic & 5 & 2.5 \\
\hline Cyprus & 21 & 2.6 \\
\hline Denmark & 7 & 1.4 \\
\hline Finland & 17 & 2.8 \\
\hline France & 20 & 4.0 \\
\hline Germany & 42 & 5.3 \\
\hline Greece & 7 & 1.4 \\
\hline Hungary & 39 & 4.9 \\
\hline Ireland & 6 & 2.0 \\
\hline Italy & 41 & 5.1 \\
\hline Lithuania & 23 & 3.8 \\
\hline Netherlands & 21 & 3.0 \\
\hline Norway & 15 & 2.1 \\
\hline Poland & 53 & 8.8 \\
\hline Portugal & 43 & 5.4 \\
\hline Romania & 100 & 12.5 \\
\hline Slovakia & 29 & 3.6 \\
\hline Spain & 45 & 5.6 \\
\hline Sweden & 17 & 2.4 \\
\hline Turkey & 27 & 3.9 \\
\hline Yugoslavia $^{1}$ & 53 & 6.6 \\
\hline Ukraine & 23 & 3.8 \\
\hline
\end{tabular}

${ }^{1}$ Slovenia and Croatia.

of orchards and vineyards obtained higher scores than weeds of the other crop systems. The difficulty of controlling perennial weeds is clearly seen by their low scores for control success, whereas annuals and biennials obtained higher scores (Fig. 2).

\subsection{Weed rankings for individual culture systems}

The fifteen weed species with the highest rankings for spread potential and weediness were often the same, but differences
Table II. Life form distribution of weed species with a high spread potential as obtained by a Europe-wide survey.

\begin{tabular}{lcc}
\hline Life form & $\mathrm{N}$ & $\%$ \\
\hline Annuals & 135 & 48.4 \\
Hemicryptophytes & 65 & 23.3 \\
Biennials & 39 & 14.0 \\
Geophytes & 30 & 10.8 \\
Aquatic plants & 3 & 1.1 \\
Nanophanerophytes & 4 & 1.4 \\
Chamaephytes & 2 & 0.7 \\
Vines & 1 & 0.4 \\
\hline
\end{tabular}

among culture systems were apparent. The species are listed in Table V. The lists contain numerous alien plants.

\subsection{Relationships of weed scores to each other}

The three weed scores exhibited only weak relationships to each other (Fig. 3). Mean score for spread potential significantly correlated with mean score for weediness (regression analysis: $\mathrm{r}^{2}=0.23, P<0.001$ ), and mean score for spread potential significantly correlated with mean score for control success (regression analysis: $\mathrm{r}^{2}=0.01, P=0.034$ ). The variation, however, was large, as was the overlap of life forms (Fig. 3).

\subsection{Relationships of weed scores to range size and crop systems}

Range size in Europe significantly correlated with mean score for spread potential (regression analysis: $\mathrm{r}^{2}=0.03, P=$ 0.002 ) but the relationship was weak (Fig. 4). There was no relationship between European range size and mean score for weediness or mean score for control success (Fig. 4).

The number of countries for which a weed was listed significantly correlated with European range size (regression analysis: $\left.\mathrm{r}^{2}=0.10, P<0.001\right)$, but again, the relationship was weak. There was also only a weak relationship between number of crop systems per species and range size (regression analysis: $\left.\mathrm{r}^{2}=0.13, P<0.001\right)$. Ranking the weeds according to their range size in Europe and relating them to the number of countries from which the species was reported as a weed reveals a sharp discrepancy between range size and number of countries (Fig. 5). Most of the weeds have a range that is larger than the range where they are perceived as weeds.

Table III. Number of weed species with a high spread potential in different crop systems as obtained by a Europe-wide survey.

\begin{tabular}{lccc}
\hline & & Life form & \\
\cline { 3 - 4 } Crop system & $\mathrm{N}$ & Annual & Biennial \\
\hline Fodder plants and pastures & 140 & 61 & 20 \\
Cereals & 186 & 103 & 21 \\
Grain legumes & 128 & 81 & 14 \\
Root crops & 140 & 81 & 22 \\
Vegetables and ornamentals & 157 & 84 & 23 \\
Orchards & 152 & 30 \\
Vineyards & 119 & 34 & 20 \\
Other agricultural areas & 36 & 67 & 14 \\
\hline
\end{tabular}




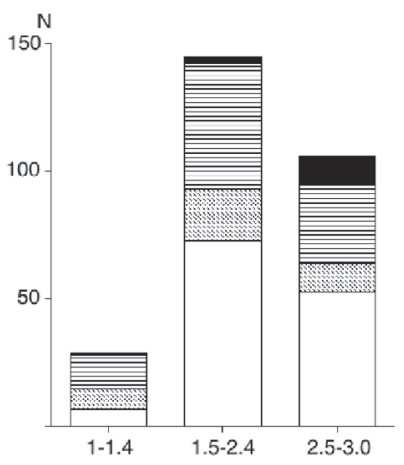

Mean score for spread potential

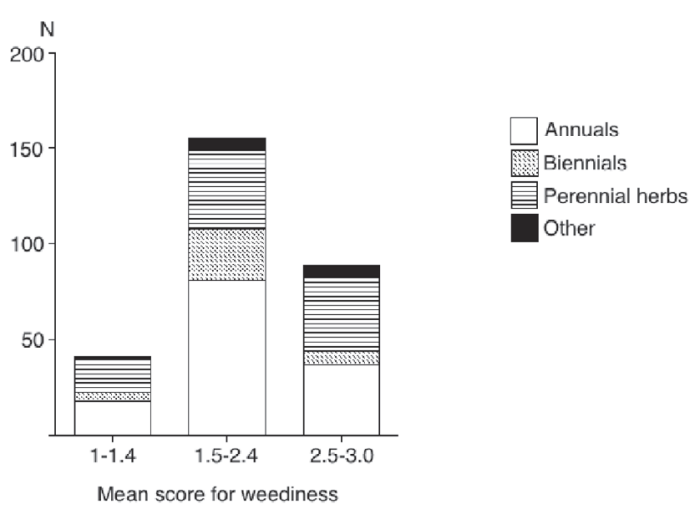

Figure 1. Histograms showing the number of weed species in classes of three different weed scores, according to perennation of the species. Data were obtained by a Europe-wide survey.

\section{DISCUSSION}

Surveys and assessing noxious weed lists are useful tools for policy-making and weed legislation, and have been compiled for various regions and purposes $[5,6,11,17,21,24]$. The present weed survey cannot be assumed to be extensive and complete, especially since the number of species listed per country varies greatly. Therefore no attempts were made to conduct detailed analyses of patterns of geographic distribution of individual species within Europe and among countries. However, for the purpose of general analyses with regard to variation in weed scores and number of weeds in different crop systems, the species obtained represent a sufficient sample size.

One aim of this survey was to obtain basic information on current weed problems in European countries and to evaluate species that could increase in their significance as weeds in the future. Assessments of problem species are often made by asking experts [5, 6] and such a direct approach may give meaningful results for the management of weeds. Whereas extensive field studies would be necessary to quantify the abundance and diversity of weeds, a survey is a fast and inexpensive approach allowing one to cover a large area.

The species list obtained (see Appendix 1) is rather extensive and demonstrates that weeds are still a significant problem in European agriculture. Several authors have pointed out that weed floras have changed rapidly within the last few decades
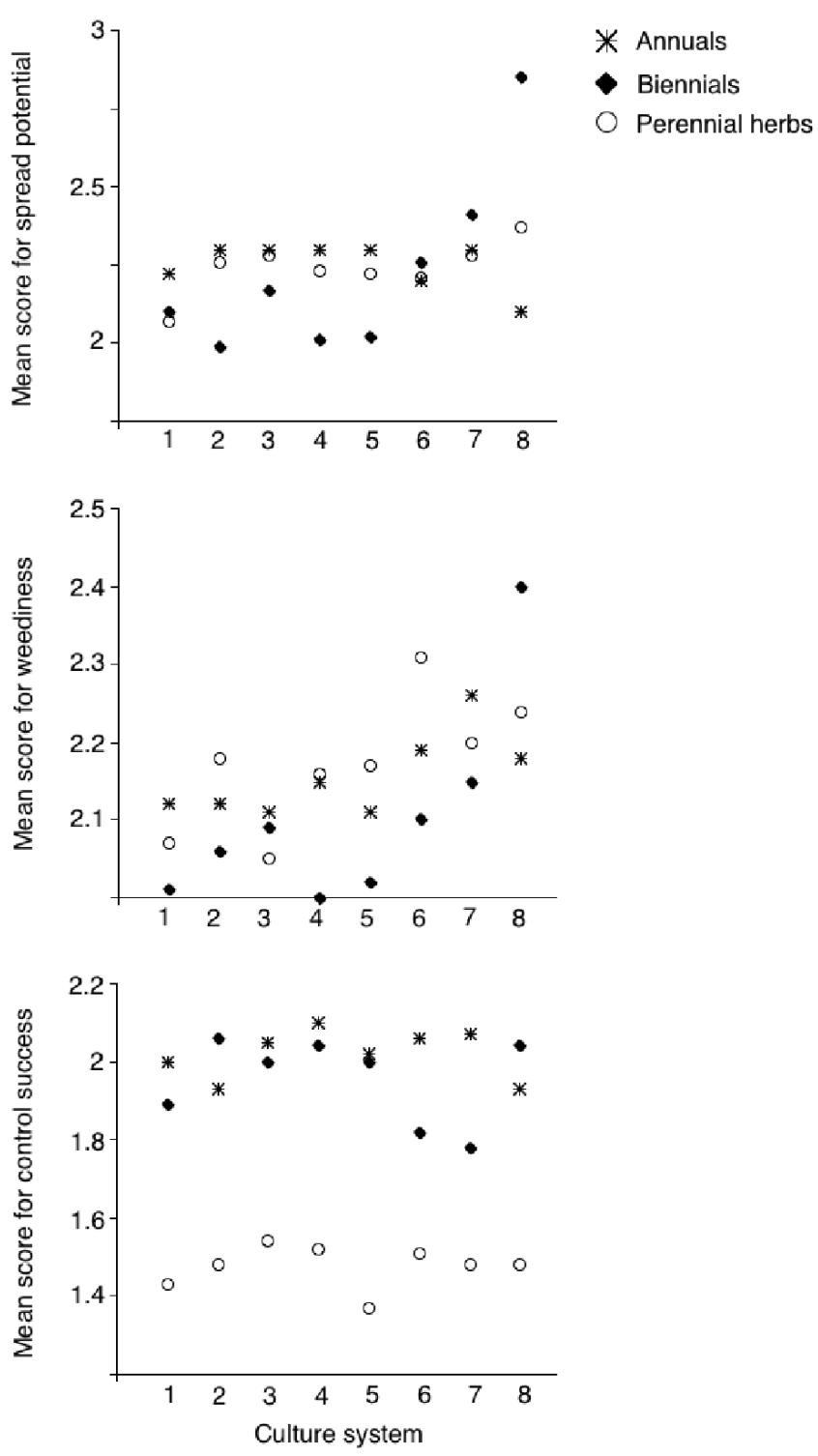

Figure 2. Mean values for three different weed scores of weed species occurring in different crop systems. Data were obtained by a Europewide survey. Crop systems: (1) fodder plants and pastures, (2) cereals, (3) grain legumes, (4) root crops, (5) vegetables and ornamentals, (6) orchards, (7) vineyards, and (8) other agricultural areas.

Table IV. Test for differences in weed scores and geographic distribution among three life forms of European weeds. Table entries are analysis of variance results. Minimum, mean and maximum scores refer to values within species.

\begin{tabular}{lcc}
\hline Character & F-value & $P$-value \\
\hline Score for spread potential & 3.9 & $0.020^{*}$ \\
Score for weediness & 0.51 & 0.601 \\
Score for control success & 19.5 & $<0.001 * * *$ \\
Number of crop systems & 6.0 & $0.003 * *$ \\
Number of countries listed & 2.8 & 0.064 \\
European range size (No. of countries) & 2.2 & 0.116 \\
\hline
\end{tabular}


Table V. Troublesome weed species in different culture systems as revealed by a Europe-wide survey. For each culture system, the fifteen most significant weed species are listed. For explanations, see text. * indicates that the species is alien to Europe.

\section{Fodder plants and pastures}

Amaranthus powellii *

Amsinckia micrantha *

Cuscuta epithymum

Duchesnea indica*

Erigeron annuus *

\section{Cereals}

Acroptilon repens

Alisma plantago-aquatica

Amaranthus paniculatus *

Conyza bonariensis *

Diplachne fascicularis

\section{Grain legumes}

Amaranthus powellii *

Amsinckia micrantha *

Asclepias syriaca*

Chenopodium ficifolium

Conyza albida *

\section{Root crops}

Amaranthus paniculatus *

Amaranthus powellii *

Chenopodium ficifolium

Conyza albida *

Conyza bonariensis *

Vegetables and ornamentals

Acroptilon repens

Amaranthus paniculatus *

Amaranthus powellii *

Chenopodium ficifolium

Erigeron annuus *

\section{Orchards}

Acroptilon repens

Amaranthus paniculatus *

Conyza albida *

Conyza bonariensis *

Euphorbia nutans *

\section{Vineyards}

Acroptilon repens

Amaranthus chlorostachys *

Amaranthus paniculatus *

Conyza bonariensis *

Conyza sumatrensis *
Hordeum murinum

Lathyrus tuberosus

Malva silvestris

Phlomis fruticosa

Poa palustris

Holcus mollis

Lathyrus tuberosus

Lotus tenuis

Malva silvestris

Oryza sativa *

Conyza bonariensis *

Erigeron annuus *

Lactuca saligna

Matricaria matricarioides *

Salsola kali

Erigeron annuus *

Lactuca saligna

Lotus tenuis

Matricaria matricarioides *

Rubus caesius

Hordeum murinum

Lactuca saligna

Lotus tenuis

Malva silvestris

Orobanche aegyptica

Heracleum mantegazzianum *

Holcus mollis

Hordeum murinum

Lathyrus tuberosus

Lavatera cretica

Crepis aspera *

Holcus mollis

Hordeum murinum

Lathyrus tuberosus

Lotus tenuis
Poa trivialis

Ranunculus acris

Silene aegyptica

Veronica persica*

Xanthium italicum *

Poa palustris

Poa trivialis

Scirpus mucronatus

Silene aegyptica

Vicia villosa

Sicyos angulatus *

Silene aegyptica

Sorghum nigrum *

Veronica persica *

Xanthium italicum *

Silene aegyptica

Sorghum bicolor *

Sorghum nigrum *

Veronica persica *

Xanthium italicum *

Orobanche ramosa

Silene aegyptica

Solanum physalifolium *

Veronica persica *

Xanthium italicum *

Lotus tenuis

Malva silvestris

Ranunculus acris

Silene aegyptica

Vicia villosa

Malva silvestris

Salsola kali

Silene aegyptica

Veronica persica *

Vicia villosa due to land use and environmental changes [1, 4, 7, 9, 22]. Besides a decline in species number, these changes also included the appearance of new weeds. Large-scale surveys of weed floras are necessary to recognize potential new weeds for a region and to allow predictions of their impact. Plant species may become serious weeds due to a change in cultural practices, although the same changes can lead to a decrease of other species $[14,19]$. New weeds may arise through immigration of expanding species or the beginning of spread of already present species.
The most significant weed species identified in this study in terms of their distribution are mostly the same as found by [23] and [10], with the exception of Abutilon theophrasti, Sinapis arvensis, Sorghum halepense, and some other species with a small geographic distribution. Despite a substantial variation in the number of species reported for each country, a high concentration of weed species was apparent in countries bordering the Mediterranean sea and in Eastern Europe. Weed management in Eastern Europe is generally less extensive than in Western Europe, leading to species-rich weed floras. The decline in 

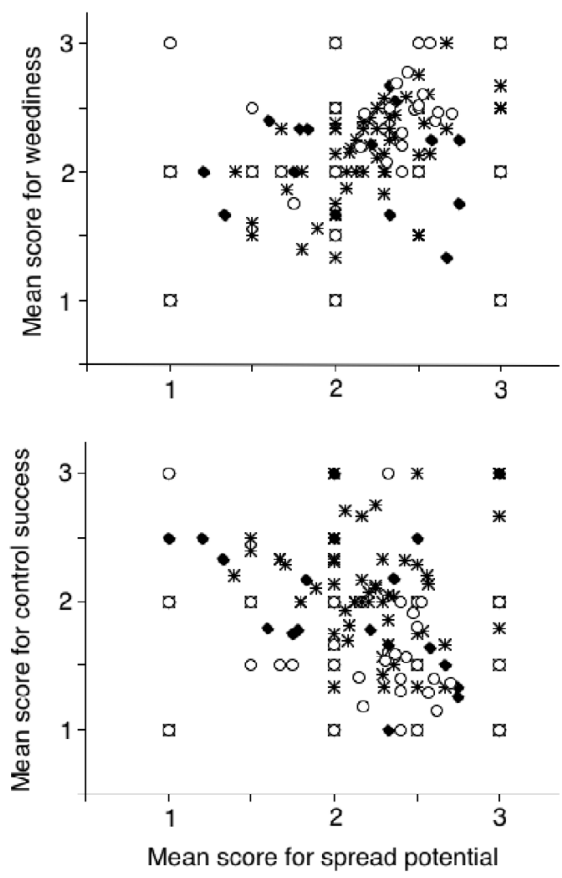

Figure 3. Relationships among three different weed scores applied to weed species of Europe. Data were obtained in a Europe-wide survey.

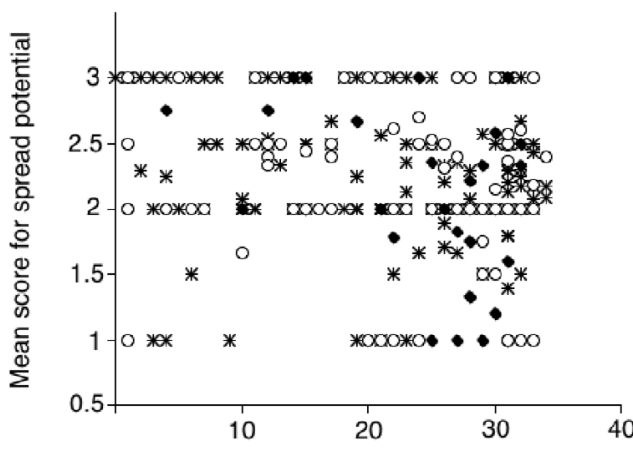

* Annuals

Biennials

Perennial herbs

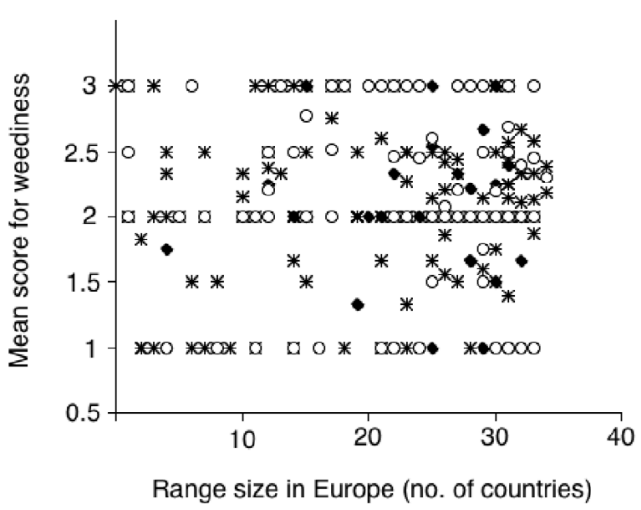

Figure 4. Relationships between weed scores and the range size in Europe. Range size is expressed as the number of countries in which the species occurs.

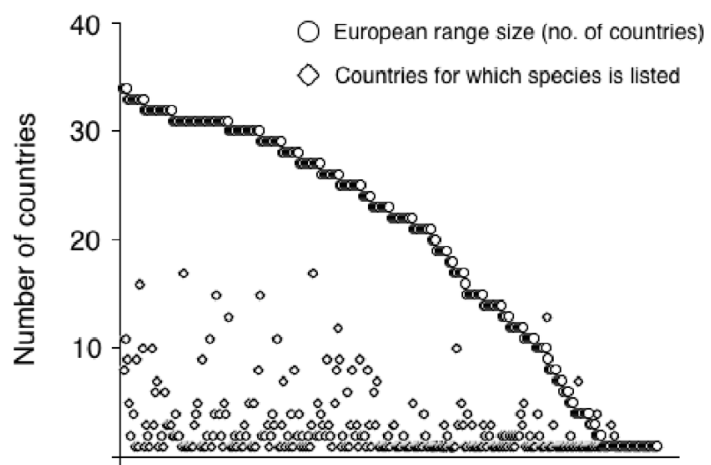

Rank of species according to range size

Figure 5. Rank of range size of weed species in Europe, with the number of countries in which the plant is perceived as a weed. Range size is expressed as the number of countries in which the species occurs.

species richness of arable land in these regions has not yet reached the levels of Western Europe. This is, for example, illustrated by Agrostemma githago, which was reported as a serious weed in Romania, but is almost extinct in Western Europe.

Whether a species is perceived as a weed or not varies from the point of view of the assessors [19,29] but also depends on the geographic location, if the plant is a weed in one country but not in another. In this study, the weed scores given by experts were not or only weakly related to range size and number of crop systems infested, suggesting that these scores reflect at least partly some aspects of the weed's ecology and not just whether the species is widespread or not. The scores are most likely associated with the life-history of the species. The three different weed scores were only weakly related to each other, again implying that they have different meanings and are associated with different aspects of the species' biology. Scores for spread potential may be related to dispersal mechanisms, and scores for weediness to the competitive ability of the weed with the crop. The scores for control success may indicate the availability of tools to control the species, as well as the ability of the species to tolerate control measures.

Several authors have related the taxonomic position of a species (family, genus) to its likelihood to become invasive. Although such an approach may be difficult, it was found that some families are highly overrepresented by weed species or invasive plants compared with the global family size $[13,20$, 27]. Mack [12] has emphasized that a species of a genus or family with weedy congeners is more likely to become a weed. Indeed, in this study, most species belong to the genera $\mathrm{Ama}$ ranthus, Bromus and Rumex, which contribute many weed species worldwide. Considering the whole set of weeds reported, diversity was high, e.g., they were distributed among many families and genera. These results make generalizations with regard to weediness and taxonomic position difficult.

The discrepancy between range size in Europe and the number of countries for which the species was listed as a weed has important implications. First, it means that species that are weeds currently in a few countries only, could expand in the 
future and become weeds in further countries. Second, it implies that there is a large potential of increasing weed problems in European agriculture. However, there could also be a bias due to different points of view of the assessors. Further studies should aim at predicting the impact of the species obtained in this survey in various regions where they are not yet present. These species need to be monitored and their appearance in new countries must be observed with caution.

Acknowledgements: We wish to thank all colleagues who returned questionnaires and provided us with sometimes very detailed information on weeds in their countries. We thank H.U. Ammon and two anonymous referees for useful comments on earlier versions of the manuscript, and C. Baroffio for translating the abstract into French.

\section{REFERENCES}

[1] Albrecht H., Changes in the arable weed flora of Germany during the last five decades, 9th EWRS Symp. Budapest, 1995, pp. 41-48.

[2] Ammon H.U., Weed control in transition - from weed eradication to vegetation management, 10th EWRS Symp. Poznan, 1997, pp. 87-94.

[3] Andow D.A., Pathways-based risk assessment of exotic species invasions, in: Ruiz G.M., Carlton J.T. (Eds.), Invasive species: vectors and management strategies, Island Press, Washington, 2003, pp. 439-455.

[4] Andreasen C., Stryhn H., Streibig J.C., Decline of the flora in Danish arable fields, J. Appl. Ecol. 33 (1996) 619-626.

[5] Batianoff G.N., Butler D.W., Assessment of invasive naturalized plants in south-east Queensland, Plant Prot. Q. 17 (2002) 27-34.

[6] Batianoff G.N., Butler D.W., Impact assessment and analysis of sixty-six priority invasive weeds in south-east Queensland, Plant Prot. Q. 18 (2003) 11-17.

[7] Davies D.H.K., New weed problems in 1996, 33rd Annual Review of Weed Control, London, 1996, pp. 21-25.

[8] Groves R.H., Panetta F.D., Virtue J.G., Weed risk assessment, CSIRO Publishing, Collingwood, 2001, Australia.

[9] Györrfy B.K., Huniady A., Kadar J., Molnar A., Hungarian national weed surveys 1950, 1992, 9th EWRS Symp. Budapest, 1992, pp. 1-10.

[10] Håkansson S., Weeds in agricultural crops. 2. Life-forms and occurrence in a European perspective, Swed. J. Agric. Res. 25 (1995) $155-161$.

[11] Karr G.W., Noxious weeds of Alabama, USA, J. Alabama Acad. Sci. 52 (1981) 32-46.

[12] Mack R.N., Biotic barriers to plant naturalization, in: Moran V.C., Hoffmann J.H. (Eds.), Proceedings of the IX International Symposium on biological control of weeds, Stellenbosch, South Africa, 1996, pp. 39-46.
[13] Maillet J., An application of weed biology: what biological criteria might be relevant to predict the invasive capacity of a new weed, 11th EWRS Symposium, 1999, Basel.

[14] McCloskey M., Firbank L.G., Watkinson A.R., Webb D.J., The dynamics of experimental arable weed communities under different management practices, J. Veg. Sci. 7 (1996) 799-808.

[15] Otte A., Die Entwicklung von Ackerwildkraut-Gesellschaften auf Böden mit guter Ertragsfähigkeit nach dem Aussetzen von Unkrautregulierungsmassnahmen, Phytocoenologia 19 (1990) 43-92.

[16] Panetta F.D., A system of assessing proposed plant introductions for weed potential, Plant Prot. Q. 8 (1993) 10-14.

[17] Panetta F.D., Scanlan J.C., Human involvement in the spread of noxious weeds: What plants should be declared and when should control be enforced? Plant Prot. Q. 10 (1995) 69-74.

[18] Patterson D.T., Weeds in a changing climate, Weed Sci. 43 (1995) 685-701.

[19] Perrins J., Williamson M., Fitter A., A survey of differing views of weed classification: implications for regulation of introductions, Biol. Conserv. 60 (1992) 47-56.

[20] Pysek P., Alien and native species in central European urban floras: a quantitative comparison, J. Biogeogr. 25 (1998) 155-163.

[21] Randall R., Garden thugs, a national list of invasive and potentially invasive garden plants, Plant Prot. Q. 16 (2001) 138-171.

[22] Sattin M., Zanin G., Berti A., Case history for weed competition/ population ecology: Velvetleaf Abutilon theophrasti. in corn Zea mays, Weed Technol. 6 (1992) 213-219.

[23] Schroeder D., Müller-Schärer H., Stinson C.S.A., A European weed survey in 10 major crop systems to identify targets for biological control, Weed Res. 33 (1993) 449-458.

[24] Skinner K., Smith L., Rice P., Using noxious weed lists to prioritize targets for developing weed management strategies, Weed Sci. 48 (2000) 640-644.

[25] Usher M.B., Biodiversity on agricultural land: habitats, species and hotspots, in: Biodiversity and conservation in agriculture, British Crop Protection Council Symposium Proceedings, Vol. 69, 1997. pp. 1-14.

[26] Vitousek P.M., D’Antonio C.M., Loope L.L., Rejmánek M. Westbrooks R., Introduced species: a significant component of human-caused global change, New Zeal. J. Ecol. 21 (1997) 1-16.

[27] Weber E., The alien flora of Europe: a taxonomic and biogeographic review, J. Veg. Sci. 8 (1997) 565-572.

[28] Westbrooks R.G., Plant protection issues. I. A commentary on new weeds in the United States, Weed Technol. 5 (1991) 232-237.

[29] Williamson M., Can the impacts of invasive species be predicted? in: Groves R.H., Panetta F.D., Virtue J.G. (Eds.), Weed risk assessment, CSIRO Publishing, Collingwood, Australia, 2001, pp. 20-33.

[30] Zamora D.L., Thill D.C., Eplee R.E., An eradication plan for plant invasions, Weed Technol. 3 (1989) 2-12. 
Appendix 1. Weed species listed in a Europe-wide survey.

\begin{tabular}{|c|c|c|c|c|c|c|c|}
\hline Species & Family & $\mathrm{LF}$ & SPR & WED & $\mathrm{CON}$ & Crop systems & Regions \\
\hline Abutilon theophrastii $*$ & Malvaceae & $\mathrm{t}$ & 2.08 & 2.15 & 1.7 & $1,2,3,4,5,6$ & C, E, S \\
\hline Achillea millefolium & Asteraceae & $\mathrm{h}$ & 1.75 & 1.75 & 1.5 & $1,3,5,6,7,8$ & E \\
\hline Acroptilon repens & Asteraceae & $\mathrm{h}$ & 2.5 & 2.5 & 1 & $2,5,6,7$ & S \\
\hline Aethusa cynapium & Apiaceae & $\mathrm{u}$ & 1.78 & 2.33 & 1.78 & 4,5 & C, E, N, S \\
\hline Agropyron repens & Poaceae & $\mathrm{g}$ & 2.48 & 2.48 & 1.91 & $1,2,3,4,5,6,7$ & $\mathrm{C}, \mathrm{E}, \mathrm{N}, \mathrm{S}$ \\
\hline Agrostemma githago & Caryophyllaceae & $\mathrm{t}$ & 2 & 2 & 2 & 2 & $\mathrm{E}$ \\
\hline Alisma plantago-aquatica & Alismataceae & a & 3 & 3 & 1 & 2 & S \\
\hline Allium oleraceum & Liliaceae & $\mathrm{g}$ & 2 & 1 & 1 & $1,5,6,7,8$ & $\mathrm{E}$ \\
\hline Allium rotundum & Liliaceae & g & 1 & 1 & 1 & 1 & $\mathrm{E}$ \\
\hline Alopecurus geniculatus & Poaceae & $\mathrm{h}$ & 2.5 & 2 & 1 & $1,2,4,5$ & $\mathrm{~N}$ \\
\hline Alopecurus myosuroides & Poaceae & $\mathrm{t}$ & 2.21 & 2.21 & 2.08 & $1,2,3,4,5,6$ & C, E, N, S \\
\hline Amaranthus albus * & Amaranthaceae & $\mathrm{t}$ & 1.67 & 2 & 2.33 & $1,2,3,4,6,7$ & $\mathrm{E}, \mathrm{S}$ \\
\hline Amaranthus blitoides * & Amaranthaceae & $\mathrm{t}$ & 2 & 2 & 3 & $2,3,4,5$ & $\mathrm{E}, \mathrm{S}$ \\
\hline Amaranthus chlorostachys * & Amaranthaceae & $\mathrm{t}$ & 2 & 2.5 & 2.5 & $1,3,4,5,6,7$ & $\mathrm{E}$ \\
\hline Amaranthus hybridus * & Amaranthaceae & $\mathrm{t}$ & 2.5 & 2.5 & 2 & $2,3,4,5,6,7$ & $S$ \\
\hline Amaranthus paniculatus * & Amaranthaceae & $\mathrm{t}$ & 3 & 3 & 2 & $2,4,5,6,7$ & E \\
\hline Amaranthus powellii * & Amaranthaceae & $\mathrm{t}$ & 3 & 2.5 & 2 & $1,2,3,4,5,6,7$ & E \\
\hline Amaranthus retroflexus * & Amaranthaceae & $\mathrm{t}$ & 2.33 & 2.42 & 2.05 & $1,2,3,4,5,6,7,8$ & $\mathrm{C}, \mathrm{E}, \mathrm{N}, \mathrm{S}$ \\
\hline Ambrosia artemisiifolia * & Asteraceae & $\mathrm{t}$ & 2.54 & 2.38 & 1.77 & $1,2,3,4,5,6,7,8$ & C, E, S \\
\hline Ammi majus & Apiaceae & $\mathrm{t}$ & 2.33 & 2.33 & 1.67 & $2,4,5$ & $S$ \\
\hline Amsinckia micrantha $*$ & Boraginaceae & $\mathrm{t}$ & 3 & 2 & 3 & $1,2,3$ & $\mathrm{~N}$ \\
\hline Amsinckia sp. * & Boraginaceae & $\mathrm{t}$ & 3 & 3 & 2 & 2 & $\mathrm{~N}$ \\
\hline Anagallis arvensis & Primulaceae & $\mathrm{t}$ & 1.8 & 1.4 & 2 & $1,2,3,4,5,6,7$ & $\mathrm{E}, \mathrm{N}, \mathrm{S}$ \\
\hline Anchusa arvensis & Boraginaceae & $\mathrm{u}$ & 1 & 1.5 & 1.5 & $3,4,5$ & $\mathrm{C}, \mathrm{E}$ \\
\hline Anthemis arvensis & Asteraceae & $\mathrm{t}$ & 1.8 & 2 & 2 & $1,2,3,4,5,6,7$ & $\mathrm{E}, \mathrm{S}$ \\
\hline Anthemis austriaca & Asteraceae & $\mathrm{u}$ & 2 & 2 & 2 & $1,2,3,6,7$ & $\mathrm{E}$ \\
\hline Apera spica-venti & Poaceae & $\mathrm{h}$ & 2.53 & 2.6 & 2 & $1,2,3,4$ & $\mathrm{E}, \mathrm{N}, \mathrm{S}$ \\
\hline Araujia sericifera $*$ & Asclepiadaceae & $\mathrm{p}$ & 1 & 2 & 1 & 6 & $S$ \\
\hline Arctium lappa & Asteraceae & $\mathrm{h}$ & 2 & 3 & 1 & $2,5,6,7,8$ & $\mathrm{E}$ \\
\hline Arrhenatherum elatius & Poaceae & $\mathrm{h}$ & 2 & 2 & 2 & 2 & $\mathrm{~N}$ \\
\hline Artemisia absinthium & Asteraceae & $\mathrm{c}$ & 2 & 2 & 1 & $1,2,5,6,7$ & $\mathrm{E}$ \\
\hline Artemisia vulgaris & Asteraceae & $\mathrm{h}$ & 2.4 & 2.2 & 1.4 & $2,3,4,5,6,7$ & E, N, S \\
\hline Asclepias syriaca * & Asclepiadaceae & $\mathrm{g}$ & 3 & 1 & 1 & $2,3,4$ & $\mathrm{E}$ \\
\hline Aster squamatus * & Asteraceae & $\mathrm{u}$ & 2.75 & 2.25 & 1.25 & $1,6,7$ & $\mathrm{C}, \mathrm{S}$ \\
\hline Atriplex patula & Chenopodiaceae & $\mathrm{t}$ & 2.5 & 2 & 1.5 & $1,2,3,5,6,7$ & $\mathrm{E}, \mathrm{N}$ \\
\hline Avena barbata & Poaceae & $\mathrm{t}$ & 2 & 2 & 2 & $2,6,7$ & $S$ \\
\hline Avena fatua & Poaceae & $\mathrm{t}$ & 2.57 & 2.14 & 2.14 & $1,2,3,4,5,6$ & C, E, N, S \\
\hline Avena sterilis & Poaceae & $\mathrm{t}$ & 2.25 & 2.5 & 2.75 & $2,3,6,7$ & $S$ \\
\hline Barbarea vulgaris & Brassicaceae & $\mathrm{u}$ & 2.33 & 2.67 & 1 & 1,4 & $\mathrm{C}, \mathrm{E}, \mathrm{N}$ \\
\hline Bidens tripartita & Asteraceae & $\mathrm{t}$ & 2.29 & 2 & 1.57 & $2,3,4,5$ & $\mathrm{C}, \mathrm{S}$ \\
\hline Bidens vulgata $*$ & Asteraceae & $\mathrm{t}$ & - & 1 & 3 & 3,4 & $\mathrm{E}$ \\
\hline Bifora radians & Asteraceae & $\mathrm{t}$ & 2.5 & 2 & 1.75 & 2 & E, $S$ \\
\hline Bothriochloa ischaemum & Poaceae & $\mathrm{h}$ & - & 3 & 1 & 1 & E \\
\hline Brassica napus & Brassicaceae & $\mathrm{u}$ & 3 & 2 & 2 & 4 & $\mathrm{E}$ \\
\hline Bromus catharticus * & Poaceae & $\mathrm{u}$ & 2 & 1 & - & $1,5,6$ & $S$ \\
\hline Bromus commutatus & Poaceae & $\mathrm{t}$ & 2 & 2 & 1 & 2 & $\mathrm{~N}$ \\
\hline Bromus diandrus & Poaceae & $\mathrm{t}$ & 2 & 2 & 1.5 & $2,6,7$ & $\mathrm{~N}, \mathrm{~S}$ \\
\hline Bromus mollis & Poaceae & $\mathrm{t}$ & 2.5 & 2.5 & 1.5 & 2,3 & $\mathrm{~N}$ \\
\hline Bromus rigidus & Poaceae & $\mathrm{t}$ & 2 & 3 & 1 & 2 & S \\
\hline
\end{tabular}


Appendix 1. Continued.

\begin{tabular}{|c|c|c|c|c|c|c|c|}
\hline Species & Family & LF & SPR & WED & $\mathrm{CON}$ & Crop systems & Regions \\
\hline Bromus secalinus & Poaceae & $\mathrm{t}$ & 2 & 2 & 1 & $2,3,4,7$ & $\mathrm{C}, \mathrm{N}, \mathrm{S}$ \\
\hline Bromus sterilis & Poaceae & $\mathrm{t}$ & 2.29 & 2.14 & 1.43 & $1,2,7$ & $\mathrm{C}, \mathrm{E}, \mathrm{N}$ \\
\hline Calamagrostis epigejos & Poaceae & $\mathrm{h}$ & 3 & 3 & 1.5 & $1,6,7,8$ & $\mathrm{E}$ \\
\hline Calystegia sepium & Convolvulaceae & $\mathrm{g}$ & 2.4 & 2.2 & 1.8 & $2,4,5,6,7$ & C, E, S \\
\hline Cannabis sativa & Cannabaceae & $\mathrm{t}$ & 1 & 2 & 1 & 3,4 & $\mathrm{E}$ \\
\hline Capsella bursa-pastoris & Brassicaceae & $\mathrm{t}$ & 2.07 & 1.87 & 2.71 & $1,2,3,4,5,6,7$ & C, E, S \\
\hline Cardamine hirsuta & Brassicaceae & $\mathrm{t}$ & 2.67 & 2.33 & 1.33 & $2,5,6$ & $\mathrm{C}, \mathrm{S}$ \\
\hline Cardaria draba & Brassicaceae & $\mathrm{h}$ & 2 & 2 & 2 & $2,3,6,7$ & $\mathrm{E}$ \\
\hline Carduus acanthoides & Asteraceae & $\mathrm{h}$ & 1 & 1 & 2 & 1 & $\mathrm{E}$ \\
\hline Carduus nutans & Asteraceae & $\mathrm{u}$ & 2 & 2 & 1 & $1,5,6,7$ & $\mathrm{E}$ \\
\hline Centaurea cyanus & Asteraceae & $\mathrm{u}$ & 1.83 & 2.33 & 2.17 & $1,2,3,4,5,6,7$ & $\mathrm{E}, \mathrm{S}$ \\
\hline Centaurea diluta & Asteraceae & $\mathrm{h}$ & 2 & 3 & 2 & $2,3,4$ & $\mathrm{~S}$ \\
\hline Centaurea scabiosa & Asteraceae & $\mathrm{h}$ & 2 & 2 & 1 & $1,2,5,6$ & $\mathrm{E}$ \\
\hline Chamaemelum fuscatum & Asteraceae & $\mathrm{t}$ & 2 & 2 & 2 & $2,6,7$ & $S$ \\
\hline Chamaemelum mixtum & Asteraceae & $\mathrm{t}$ & 2 & 2 & 2 & $2,6,7$ & $S$ \\
\hline Chenopodium album & Chenopodiaceae & $\mathrm{t}$ & 2.43 & 2.58 & 2.32 & $1,2,3,4,5,6,7,8$ & $\mathrm{C}, \mathrm{E}, \mathrm{N}, \mathrm{S}$ \\
\hline Chenopodium ficifolium & Chenopodiaceae & $\mathrm{t}$ & 3 & 2 & 3 & $2,3,4,5$ & $S$ \\
\hline Chenopodium hybridum & Chenopodiaceae & $\mathrm{t}$ & 1.5 & 2 & 2.5 & $1,2,3,4,5,6,7$ & E, S \\
\hline Chenopodium polyspermum & Chenopodiaceae & $\mathrm{t}$ & 2 & 1.5 & 2.5 & $2,3,4,5,6,7$ & $\mathrm{E}, \mathrm{S}$ \\
\hline Chenopodium rubrum & Chenopodiaceae & $\mathrm{t}$ & - & 2 & 3 & $3,4,5$ & $\mathrm{E}$ \\
\hline Cichorium intybus & Asteraceae & $\mathrm{h}$ & 2 & 2 & 1 & 3 & $S$ \\
\hline Cirsium arvense & Asteraceae & $\mathrm{g}$ & 2.37 & 2.69 & 1.59 & $1,2,3,4,5,6,7,8$ & C, E, N, S \\
\hline Cirsium setosum & Asteraceae & $\mathrm{g}$ & 1 & 1 & 1 & $1,2,3,4,5,6,8$ & $\mathrm{E}$ \\
\hline Conium maculatum & Apiaceae & $\mathrm{u}$ & 1.6 & 2.4 & 1.8 & $1,2,4,5$ & $\mathrm{C}, \mathrm{E}$ \\
\hline Consolida orientalis & Ranunculaceae & $\mathrm{t}$ & 3 & 2 & 1 & 2 & $S$ \\
\hline Consolida regalis & Ranunculaceae & $\mathrm{t}$ & 1 & 1 & 1 & $1,2,8$ & $\mathrm{E}$ \\
\hline Convolvulus arvensis & Convolvulaceae & $\mathrm{g}$ & 2.15 & 2.19 & 1.41 & $1,2,3,4,5,6,7,8$ & C, E, S \\
\hline Conyza albida * & Asteraceae & $\mathrm{t}$ & 3 & 3 & 2 & $2,3,4,6,7$ & $S$ \\
\hline Conyza bonariensis * & Asteraceae & $\mathrm{t}$ & 3 & 3 & 1.5 & $2,3,4,6,7$ & $\mathrm{~S}$ \\
\hline Conyza canadensis * & Asteraceae & $\mathrm{u}$ & 2.58 & 2.25 & 1.64 & $1,2,3,4,5,6,7$ & C, E, S \\
\hline Conyza sumatrensis $*$ & Asteraceae & $\mathrm{t}$ & 3 & 3 & 2 & 7 & $\mathrm{C}$ \\
\hline Corchorus olitorius * & Tiliaceae & $\mathrm{t}$ & 3 & 1 & 1 & 3,5 & $S$ \\
\hline Coronilla varia & Fabaceae & $\mathrm{h}$ & 2 & 1 & 1 & $1,3,5,6,7$ & $\mathrm{E}$ \\
\hline Crepis aspera* & Asteraceae & $\mathrm{t}$ & 3 & 3 & 3 & 7 & S \\
\hline Crepis bursifolia & Asteraceae & $\mathrm{g}$ & 2 & 1 & - & 5 & $S$ \\
\hline Cuscuta campestris * & Cuscutaceae & $\mathrm{t}$ & 2.5 & 2.75 & 1.33 & $1,3,4,5$ & E, S \\
\hline Cuscuta epithymum & Cuscutaceae & $\mathrm{t}$ & 3 & 3 & 1 & 1 & $\mathrm{~S}$ \\
\hline Cynanchum acutum & Asclepiadaceae & $\mathrm{n}$ & - & 2 & 1 & 1 & $S$ \\
\hline Cynodon dactylon & Poaceae & $\mathrm{g}$ & 2.7 & 2.45 & 1.36 & $1,2,3,4,5,6,7$ & $\mathrm{E}, \mathrm{S}$ \\
\hline Cyperus difformis & Cyperaceae & $\mathrm{t}$ & 3 & 1 & 2 & $2,4,5$ & $\mathrm{E}$ \\
\hline Cyperus eragrostis * & Cyperaceae & $\mathrm{h}$ & 2 & 1 & - & 5 & $S$ \\
\hline Cyperus esculentus & Cyperaceae & $\mathrm{g}$ & 2.4 & 2.2 & 1 & $1,2,3,4,5,6$ & $\mathrm{C}, \mathrm{S}$ \\
\hline Cyperus rotundus & Cyperaceae & $\mathrm{g}$ & 2.4 & 2 & 2 & $1,4,5,6,7$ & S \\
\hline Dactylis glomerata & Poaceae & $\mathrm{h}$ & 1 & 1 & 2 & $1,6,7$ & $S$ \\
\hline Datura innoxia * & Solanaceae & $\mathrm{t}$ & 3 & 1 & - & 5 & $S$ \\
\hline Datura stramonium * & Solanaceae & $\mathrm{t}$ & 2.07 & 2 & 1.93 & $1,2,3,4,5,6,7$ & $\mathrm{E}, \mathrm{S}$ \\
\hline Daucus carota & Apiaceae & $\mathrm{u}$ & 2.33 & 1.67 & 1.67 & $1,2,3,4,5,6,7$ & $\mathrm{C}, \mathrm{E}, \mathrm{N}$ \\
\hline Descurainia sophia & Brassicaceae & $\mathrm{u}$ & 1.2 & 2 & 2.5 & $1,2,3,4,5,6$ & $\mathrm{C}, \mathrm{E}$ \\
\hline Dichanthium saccharoides & Poaceae & $\mathrm{h}$ & 3 & 2 & 1 & 7 & $\mathrm{C}$ \\
\hline
\end{tabular}


Appendix 1. Continued.

\begin{tabular}{|c|c|c|c|c|c|c|c|}
\hline Species & Family & LF & SPR & WED & $\mathrm{CON}$ & Crop systems & Regions \\
\hline Digitaria ischaemum & Poaceae & $\mathrm{t}$ & 2 & 1 & 1 & 1,3 & $\mathrm{C}$ \\
\hline Digitaria sanguinea & Poaceae & $\mathrm{t}$ & 1.89 & 1.56 & 2.11 & $1,2,3,4,5,6,7$ & $\mathrm{E}, \mathrm{S}$ \\
\hline Diplachne fascicularis & Poaceae & $\mathrm{t}$ & 3 & 3 & 2 & 2 & $\mathrm{~S}$ \\
\hline Duchesnea indica * & Rosaceae & $\mathrm{h}$ & 3 & 2 & - & $1,5,6$ & $\mathrm{~S}$ \\
\hline Echinochloa crus-galli & Poaceae & $\mathrm{t}$ & 2.36 & 2.44 & 2.04 & $1,2,3,4,5,6,7,8$ & $\mathrm{C}, \mathrm{E}, \mathrm{N}, \mathrm{S}$ \\
\hline Echinochloa eruciformis & Poaceae & $\mathrm{t}$ & 1 & 1 & - & 6,7 & $\mathrm{~S}$ \\
\hline Echinocystis lobata* & Cucurbitaceae & $\mathrm{t}$ & 2.5 & 2.5 & 2 & $2,3,4,6$ & $\mathrm{~S}$ \\
\hline Echinophora tenuifolia & Apiaceae & $\mathrm{h}$ & - & 1 & 2 & 2,3 & $\mathrm{E}$ \\
\hline Eleusine indica * & Poaceae & $\mathrm{t}$ & 1.5 & 1.5 & 2 & $4,5,6$ & $\mathrm{C}, \mathrm{S}$ \\
\hline Epilobium ciliatum * & Onagraceae & $\mathrm{h}$ & 2.33 & 2.5 & 3 & $5,6,7$ & $\mathrm{C}, \mathrm{E}$ \\
\hline Epilobium hirsutum & Onagraceae & $\mathrm{h}$ & 2.5 & 2 & 1.5 & $2,3,4,8$ & $\mathrm{~S}$ \\
\hline Equisetum arvense & Equisetaceae & $\mathrm{g}$ & 2.18 & 2.45 & 1.18 & $1,2,3,4,5,6,7,8$ & $\mathrm{C}, \mathrm{E}, \mathrm{N}, \mathrm{S}$ \\
\hline Erigeron annuиs $*$ & Asteraceae & $\mathrm{u}$ & 3 & 2 & 2 & $1,2,3,4,5,6,7,8$ & $\mathrm{~S}$ \\
\hline Erodium cicutarium & Geraniaceae & $\mathrm{u}$ & 1 & 1 & 2 & 5 & $\mathrm{E}$ \\
\hline Euphorbia agraria & Euphorbiaceae & $\mathrm{h}$ & 2 & 2 & 1 & $1,2,5,6$ & $\mathrm{E}$ \\
\hline Euphorbia heterophylla & Euphorbiaceae & $\mathrm{t}$ & 2 & 1 & 1 & 5 & $\mathrm{~S}$ \\
\hline Euphorbia nutans $*$ & Euphorbiaceae & $\mathrm{t}$ & 3 & 3 & 3 & 6 & $\mathrm{~S}$ \\
\hline Euphorbia prostrata* & Euphorbiaceae & $\mathrm{t}$ & 2 & 2 & 2.5 & $5,6,7$ & $\mathrm{C}, \mathrm{S}$ \\
\hline Euphorbia serpens & Euphorbiaceae & $\mathrm{t}$ & 3 & 2 & 1 & 5 & $S$ \\
\hline Euphorbia virgata & Euphorbiaceae & $\mathrm{h}$ & 1 & 2 & 1 & $1,2,3,4,5,6$ & $\mathrm{E}$ \\
\hline Fallopia convolvulus & Polygonaceae & $\mathrm{t}$ & 2 & 2.33 & 1.67 & $1,2,3,4,5,6,7,8$ & C, E, S \\
\hline Fumaria officinalis & Papaveraceae & $\mathrm{t}$ & 2.17 & 2 & 2.17 & $2,4,5$ & $\mathrm{E}, \mathrm{N}, \mathrm{S}$ \\
\hline Galeopsis pubescens & Lamiaceae & $\mathrm{t}$ & - & 1 & 1 & 2 & $\mathrm{E}$ \\
\hline Galeopsis tetrahit & Lamiaceae & $\mathrm{t}$ & 1.71 & 1.86 & 2.29 & $1,2,3,4,5,6$ & $\mathrm{E}$ \\
\hline Galinsoga ciliata * & Asteraceae & $\mathrm{t}$ & 2 & 1.67 & 2.5 & $2,3,4,5$ & $\mathrm{C}, \mathrm{S}$ \\
\hline Galinsoga parviflora * & Asteraceae & $\mathrm{t}$ & 2.56 & 2.6 & 2.2 & $2,3,4,5,6,7$ & $\mathrm{E}$ \\
\hline Galium aparine & Rubiaceae & $\mathrm{t}$ & 2.21 & 2.42 & 2 & $1,2,3,4,5,6,7,8$ & $\mathrm{C}, \mathrm{E}, \mathrm{N}, \mathrm{S}$ \\
\hline Galium spurium & Rubiaceae & $\mathrm{t}$ & 2.5 & 2.5 & 1.5 & $2,3,4,5$ & $\mathrm{E}, \mathrm{S}$ \\
\hline Galium tricornutum & Rubiaceae & $\mathrm{t}$ & 1.67 & 2.33 & 2.33 & $2,3,4$ & E, S \\
\hline Geranium dissectum & Geraniaceae & $\mathrm{t}$ & 2 & 2 & 3 & 4 & $\mathrm{C}$ \\
\hline Geranium pusillum & Geraniaceae & $\mathrm{u}$ & 2 & 1.67 & 2 & 5,6 & $\mathrm{E}$ \\
\hline Glycyrrhiza glabra & Fabaceae & $\mathrm{h}$ & 2 & 1 & 1 & 1,2 & $S$ \\
\hline Gypsophila muralis & Caryophyllaceae & $\mathrm{t}$ & 3 & 2 & 1 & $1,2,5,6,7$ & $\mathrm{E}$ \\
\hline Helianthus annuus * & Asteraceae & $\mathrm{t}$ & 2.5 & 2.5 & 2 & $2,3,4,5$ & $\mathrm{E}$ \\
\hline Helianthus tuberosus * & Asteraceae & $\mathrm{g}$ & 2.5 & 2 & 2 & $2,3,4,8$ & $\mathrm{~S}$ \\
\hline Heracleum lanatum * & Apiaceae & $\mathrm{h}$ & 3 & 3 & 2 & 6 & $\mathrm{~N}$ \\
\hline Heracleum mantegazzianum * & Apiaceae & $\mathrm{h}$ & 2.44 & 2.78 & 1.57 & 6,8 & $\mathrm{C}, \mathrm{N}$ \\
\hline Heracleum sosnowskyi & Apiaceae & $\mathrm{h}$ & 1 & 3 & 3 & 6 & $\mathrm{E}$ \\
\hline Heteranthera limosa * & Pontederiaceae & a & 2.5 & 2.5 & 1.5 & 2 & $\mathrm{E}, \mathrm{S}$ \\
\hline Heteranthera reniformis $*$ & Pontederiaceae & $\mathrm{a}$ & 2.67 & 2.33 & 1.33 & 2 & $\mathrm{E}, \mathrm{S}$ \\
\hline Hibiscus trionum & Malvaceae & $\mathrm{t}$ & 2 & 1.67 & 1.67 & $1,2,3,4,5,6,7$ & $\mathrm{E}, \mathrm{S}$ \\
\hline Holcus mollis & Poaceae & $\mathrm{h}$ & 3 & 3 & 2 & $2,6,7$ & $\mathrm{~S}$ \\
\hline Hordeum murinum & Poaceae & $\mathrm{t}$ & 3 & 3 & 2 & $1,5,6,7$ & $\mathrm{E}$ \\
\hline Hypecoum imberbe & Fumariaceae & $\mathrm{t}$ & 2 & 1 & 1 & 2 & $S$ \\
\hline Inula brittannica & Asteraceae & $\mathrm{h}$ & $*$ & 3 & 1 & 5 & $\mathrm{C}$ \\
\hline Iva xanthifolia * & Asteraceae & $\mathrm{t}$ & 2.5 & 1.5 & 2 & $2,3,4,5$ & $\mathrm{E}, \mathrm{S}$ \\
\hline Juncus effusus & Juncaceae & $\mathrm{h}$ & 2 & 2.5 & 1.5 & $1,2,4$ & $\mathrm{E}$ \\
\hline Lactuca saligna & Asteraceae & $\mathrm{u}$ & 3 & 2 & 1 & $1,2,3,4,5,6,7,8$ & $\mathrm{E}$ \\
\hline Lactuca serriola & Asteraceae & $\mathrm{u}$ & 1.75 & 2 & 1.75 & $1,2,3,4,5,6,7$ & $\mathrm{E}, \mathrm{S}$ \\
\hline
\end{tabular}


Appendix 1. Continued.

\begin{tabular}{|c|c|c|c|c|c|c|c|}
\hline Species & Family & $\mathrm{LF}$ & SPR & WED & $\mathrm{CON}$ & Crop systems & Regions \\
\hline Lamium amplexicaule & Lamiaceae & $\mathrm{u}$ & 2.5 & 2 & 2.5 & 5 & $\mathrm{E}$ \\
\hline Lamium purpureum & Lamiaceae & $\mathrm{t}$ & 2 & 1.75 & 1.75 & $2,3,4,5,6$ & $\mathrm{C}, \mathrm{E}$ \\
\hline Lapsana communis & Asteraceae & $\mathrm{t}$ & 2 & 2.5 & 2 & $1,2,4,5,6,7$ & $\mathrm{E}, \mathrm{N}$ \\
\hline Lathyrus tuberosus & Fabaceae & $\mathrm{g}$ & 3 & 3 & 1 & $1,2,6,7$ & $\mathrm{E}$ \\
\hline Lavatera cretica & Malvaceae & $\mathrm{u}$ & 3 & 3 & 1 & 6 & $S$ \\
\hline Leersia oryzoides & Poaceae & $\mathrm{g}$ & 2.5 & 3 & 1.5 & 2 & $\mathrm{C}, \mathrm{S}$ \\
\hline Lolium multiflorum & Poaceae & $\mathrm{h}$ & 1 & 2 & 1 & 2,4 & $S$ \\
\hline Lolium rigidum & Poaceae & $\mathrm{t}$ & 2.5 & 1.5 & 2 & $2,6,7$ & S \\
\hline Lotus tenuis & Fabaceae & $\mathrm{h}$ & 3 & 3 & 1 & $2,4,5,6,7$ & $\mathrm{E}$ \\
\hline Lysimachia punctata & Primulaceae & $\mathrm{h}$ & 1 & 1 & 3 & 1 & $\mathrm{E}$ \\
\hline Malva neglecta & Malvaceae & $\mathrm{u}$ & 2 & 2 & 1.5 & $1,4,5,6$ & $\mathrm{E}$ \\
\hline Malva silvestris & Malvaceae & $\mathrm{u}$ & 3 & 3 & 3 & $1,2,5,6,7,8$ & S \\
\hline Matricaria chamomilla & Asteraceae & $\mathrm{t}$ & 1.5 & 1.6 & 2.4 & $1,2,3,4,5,6,7$ & E, S \\
\hline Matricaria inodora & Asteraceae & $\mathrm{u}$ & 2.36 & 2.55 & 2.18 & $1,2,3,4,5,6,7,8$ & C, E, S \\
\hline Matricaria matricarioides $*$ & Asteraceae & $\mathrm{t}$ & 3 & 2 & 2 & $2,3,4,5,6$ & $\mathrm{~N}$ \\
\hline Matricaria perforata & Asteraceae & $\mathrm{t}$ & 2 & 1.67 & 1.33 & $1,2,3,6,8$ & $\mathrm{E}$ \\
\hline Melampyrum arvense & Scrophulariaceae & $\mathrm{t}$ & 1 & 1 & 2 & 1 & $\mathrm{E}$ \\
\hline Mentha arvensis & Lamiaceae & $\mathrm{g}$ & 2 & 2 & 2 & 2 & $\mathrm{C}$ \\
\hline Mentha longifolia & Lamiaceae & $\mathrm{g}$ & 1 & 1 & 2 & $1,6,7$ & $\mathrm{E}$ \\
\hline Mercurialis аппиа & Euphorbiaceae & $\mathrm{u}$ & 1.33 & 1.67 & 2.33 & $4,5,6,7$ & $\mathrm{C}, \mathrm{E}$ \\
\hline Myosotis arvensis & Boraginaceae & $\mathrm{t}$ & 2.5 & 1.5 & 1 & $2,3,4$ & $\mathrm{C}, \mathrm{E}$ \\
\hline Nardus stricta & Poaceae & $\mathrm{h}$ & 2 & 2.5 & 1.5 & 1 & E, S \\
\hline Nigella arvensis & Ranunculaceae & $\mathrm{t}$ & 2 & 1 & 1 & 2 & $S$ \\
\hline Oenanthe spree & Apiaceae & $\mathrm{h}$ & 2 & 2 & 1 & 1 & $\mathrm{C}$ \\
\hline Orobanche aegyptica & Orobanchaceae & $\mathrm{t}$ & 3 & 3 & 2 & 5 & $\mathrm{~S}$ \\
\hline Orobanche ramosa & Orobanchaceae & $\mathrm{t}$ & 3 & 3 & 2 & 5 & $S$ \\
\hline Oryza sativa $*$ & Poaceae & $\mathrm{t}$ & 3 & 3 & 1 & 2 & $S$ \\
\hline Oxalis latifolia $*$ & Oxalidaceae & $\mathrm{g}$ & 2 & 3 & 1 & 5 & $S$ \\
\hline Oxalis pes-caprae * & Oxalidaceae & $\mathrm{g}$ & 2.5 & 2 & 1.5 & $2,5,6,7$ & S \\
\hline Paliurus aculeatus & Rhamnaceae & $\mathrm{j}$ & 2 & 2 & 1 & 1 & $S$ \\
\hline Panicum capillare * & Poaceae & $\mathrm{t}$ & 2.5 & 2 & 3 & $2,3,4,5,7$ & $S$ \\
\hline Panicum dichotomiflorum * & Poaceae & $\mathrm{t}$ & 2.29 & 1.83 & 2 & $1,2,3,4,5,6,7$ & $\mathrm{C}, \mathrm{S}$ \\
\hline Panicum miliaceum $*$ & Poaceae & $\mathrm{t}$ & 2.67 & 3 & 1.67 & $2,3,4,5$ & C, E, S \\
\hline Papaver rhoeas & Papaveraceae & $\mathrm{t}$ & 2.13 & 2.25 & 2 & $1,2,3,4,5,6,7$ & $\mathrm{C}, \mathrm{E}, \mathrm{N}, \mathrm{S}$ \\
\hline Parietaria officinalis & Urticaceae & $\mathrm{h}$ & 1 & 3 & 1 & 6 & $S$ \\
\hline Paspalum dilatatum & Poaceae & $\mathrm{g}$ & 1 & 1 & 2 & 7 & $\mathrm{C}$ \\
\hline Paspalum distichum * & Poaceae & $\mathrm{h}$ & 1.67 & 2 & 1.5 & $1,5,6$ & $\mathrm{~S}$ \\
\hline Pennisetum clandestinum & Poaceae & $\mathrm{h}$ & 2 & 3 & 1 & 5 & $S$ \\
\hline Phalaris paradoxa & Poaceae & $\mathrm{t}$ & 2 & 2.33 & 2.33 & $1,2,5,7$ & $\mathrm{~N}, \mathrm{~S}$ \\
\hline Phleum pratense & Poaceae & $\mathrm{h}$ & 1 & 1 & 2 & 1,2 & $S$ \\
\hline Phlomis fruticosa & Lamiaceae & $\mathrm{n}$ & 3 & 3 & 1 & 1 & $S$ \\
\hline Phragmites communis & Poaceae & $\mathrm{g}$ & 3 & 2 & 1 & $2,3,4,5$ & $\mathrm{E}, \mathrm{S}$ \\
\hline Picris echioides & Asteraceae & $\mathrm{u}$ & 2 & 3 & 2 & 3,5 & $S$ \\
\hline Plantago lanceolata & Plantaginaceae & $\mathrm{h}$ & 2 & 2 & 2 & $1,2,3,4,5,6,7$ & $\mathrm{E}, \mathrm{S}$ \\
\hline Plantago major & Plantaginaceae & $\mathrm{h}$ & 1 & 1 & 2 & 5 & $\mathrm{E}$ \\
\hline Роа аппиа & Poaceae & $\mathrm{t}$ & 2.3 & 2 & 1.33 & $1,2,3,4,5,6,7$ & $\mathrm{C}, \mathrm{E}, \mathrm{N}, \mathrm{S}$ \\
\hline Poa palustris & Poaceae & $\mathrm{h}$ & 3 & 3 & 1 & 1,2 & $\mathrm{~N}$ \\
\hline Poa trivialis & Poaceae & $\mathrm{h}$ & 3 & 3 & 1 & 1,2 & $\mathrm{~N}$ \\
\hline Polygonum amphibium & Polygonaceae & $\mathrm{g}$ & 3 & 1 & 1 & 1,5 & $\mathrm{E}$ \\
\hline
\end{tabular}


Appendix 1. Continued.

\begin{tabular}{|c|c|c|c|c|c|c|c|}
\hline Species & Family & LF & SPR & WED & $\mathrm{CON}$ & Crop systems & Regions \\
\hline Polygonum aviculare & Polygonaceae & $\mathrm{t}$ & 2.09 & 2.18 & 1.82 & $1,2,3,4,5,6,7$ & $\mathrm{C}, \mathrm{E}, \mathrm{N}, \mathrm{S}$ \\
\hline Polygonum lapathifolium & Polygonaceae & $\mathrm{t}$ & 1.4 & 2 & 2.2 & $1,2,3,4,5,6,7,8$ & C, E, S \\
\hline Polygonum persicaria & Polygonaceae & $\mathrm{t}$ & 2.25 & 2.11 & 2.11 & $1,2,3,4,5,6,7$ & $\mathrm{E}, \mathrm{S}$ \\
\hline Portulaca oleracea * & Portulacaceae & $\mathrm{t}$ & 2.25 & 2.33 & 2.13 & $1,2,3,4,5,6,7,8$ & E, $S$ \\
\hline Prosopis farcta $*$ & Fabaceae & $\mathrm{h}$ & 2 & 2 & 1 & 2 & $\mathrm{~S}$ \\
\hline Pteridium aquilinum & Pteridiaceae & $\mathrm{g}$ & 2.57 & 3 & 1.29 & $1,4,6,7,8$ & $\mathrm{E}, \mathrm{N}, \mathrm{S}$ \\
\hline Ranunculus acris & Ranunculaceae & $\mathrm{h}$ & 3 & 3 & 1 & 1,6 & $\mathrm{~N}$ \\
\hline Ranunculus arvensis & Ranunculaceae & $\mathrm{t}$ & 2 & 2 & 2 & $1,2,6$ & $\mathrm{E}$ \\
\hline Ranunculus repens & Ranunculaceae & $\mathrm{h}$ & 2 & 2 & 1 & 1,6 & E, $N$ \\
\hline Raphanus raphanistrum & Brassicaceae & $\mathrm{t}$ & 2.17 & 2.33 & 2.67 & $1,2,3,4,5,6,7$ & $\mathrm{E}, \mathrm{S}$ \\
\hline Reynoutria japonica * & Polygonaceae & $\mathrm{g}$ & 2.62 & 2.46 & 1.15 & $2,3,4,6$ & $\mathrm{C}, \mathrm{N}, \mathrm{S}$ \\
\hline Reynoutria sachalinensis * & Polygonaceae & $\mathrm{g}$ & 2 & 2.5 & 1.67 & $2,3,4,6$ & $\mathrm{C}, \mathrm{N}, \mathrm{S}$ \\
\hline Rorippa silvestris & Brassicaceae & $\mathrm{h}$ & 2 & 2 & 1 & $4,5,6$ & E, $N$ \\
\hline Rubus caesius & Rosaceae & $\mathrm{n}$ & 3 & 2 & 1 & $1,2,4,5,6,7,8$ & $\mathrm{C}$ \\
\hline Rubus ulmifolius & Rosaceae & $\mathrm{n}$ & 2 & - & 1 & 6,7 & $\mathrm{~S}$ \\
\hline Rudbeckia laciniata * & Asteraceae & $\mathrm{g}$ & 2 & 1 & 2 & $2,3,4$ & $\mathrm{~S}$ \\
\hline Rumex acetosella & Polygonaceae & $\mathrm{h}$ & 2 & 2 & 1.5 & $1,2,3,4,5,6,7,8$ & $\mathrm{~S}$ \\
\hline Rumex bucephalophorus & Polygonaceae & $\mathrm{t}$ & 2 & 2 & 2 & $2,6,7$ & $S$ \\
\hline Rumex conglomeratus & Polygonaceae & $\mathrm{h}$ & 2 & 3 & 2 & $1,5,6$ & $\mathrm{~S}$ \\
\hline Rumex crispus & Polygonaceae & $\mathrm{h}$ & 2.6 & 2.4 & 1.4 & $1,2,3,4,5,6,7$ & $\mathrm{E}, \mathrm{S}$ \\
\hline Rumex longifolius & Polygonaceae & $\mathrm{h}$ & 2.5 & 3 & 2 & 1 & $\mathrm{~N}$ \\
\hline Rumex obtusifolius & Polygonaceae & $\mathrm{h}$ & 1.5 & 2.5 & 2 & $1,5,6$ & $\mathrm{E}, \mathrm{S}$ \\
\hline Rumex pulcher & Polygonaceae & $\mathrm{h}$ & 2 & 3 & 2 & $1,5,6$ & $\mathrm{~S}$ \\
\hline Sagina procumbens & Caryophyllaceae & $\mathrm{c}$ & 2 & 2 & 2 & 5 & $\mathrm{C}$ \\
\hline Salsola kali & Chenopodiaceae & $\mathrm{t}$ & 3 & 3 & 1 & $2,3,7$ & $\mathrm{~S}$ \\
\hline Salvia reflexa & Lamiaceae & $\mathrm{t}$ & 2 & 2 & - & 1 & $\mathrm{E}$ \\
\hline Sanguisorba minor & Rosaceae & $\mathrm{h}$ & 1 & 1 & 2 & 1 & $\mathrm{E}$ \\
\hline Scandix pecten-veneris & Apiaceae & $\mathrm{t}$ & 2 & 2.5 & 2 & $1,2,3,4,5,6,7$ & $\mathrm{~N}, \mathrm{~S}$ \\
\hline Scirpus maritimus & Cyperaceae & $\mathrm{g}$ & 1 & 2 & 1 & 2,4 & $\mathrm{C}$ \\
\hline Scirpus mucronatus & Cyperaceae & $\mathrm{h}$ & 3 & 3 & 1 & 2 & $\mathrm{~S}$ \\
\hline Scleranthus annuus & Caryophyllaceae & $\mathrm{u}$ & 2 & 1.5 & 2.5 & $2,3,4$ & $\mathrm{E}$ \\
\hline Secale cereale & Poaceae & $\mathrm{u}$ & 2 & 3 & 2 & 2 & $\mathrm{~S}$ \\
\hline Senecio inaequidens * & Asteraceae & $\mathrm{u}$ & 2.75 & 1.75 & 1.33 & 1 & $\mathrm{C}, \mathrm{S}$ \\
\hline Senecio vernalis & Asteraceae & $\mathrm{u}$ & 2.67 & 1.33 & 1.5 & 1,4 & $\mathrm{C}, \mathrm{N}$ \\
\hline Senecio vulgaris & Asteraceae & $\mathrm{t}$ & 2.5 & 2.13 & 2.29 & $3,4,5,6,7,8$ & $\mathrm{C}, \mathrm{E}$ \\
\hline Setaria glauca & Poaceae & $\mathrm{t}$ & 2 & 2.14 & 2.14 & $1,2,3,4,5,6,7,8$ & $\mathrm{E}, \mathrm{S}$ \\
\hline Setaria verticillata & Poaceae & $\mathrm{t}$ & 2 & 2 & 2.33 & $1,2,3,4,5,6,7$ & $\mathrm{C}, \mathrm{S}$ \\
\hline Setaria viridis & Poaceae & $\mathrm{t}$ & 2.13 & 2 & 2 & $1,2,3,4,5,6,7$ & $\mathrm{C}, \mathrm{E}, \mathrm{N}, \mathrm{S}$ \\
\hline Sicyos angulatus * & Cucurbitaceae & $\mathrm{t}$ & 3 & 1 & - & $1,2,3$ & $\mathrm{~S}$ \\
\hline Silene aegyptica & Caryophyllaceae & $\mathrm{t}$ & 3 & 3 & 3 & $1,2,3,4,5,6,7$ & $\mathrm{~S}$ \\
\hline Silybum marianum & Asteraceae & $\mathrm{u}$ & 2 & 2 & 2 & 2 & $\mathrm{~S}$ \\
\hline Sinapis arvensis & Brassicaceae & $\mathrm{t}$ & 2 & 2.38 & 2.31 & $1,2,3,4,5,6,7,8$ & $\mathrm{E}, \mathrm{S}$ \\
\hline Sisymbrium altissimum & Brassicaceae & $\mathrm{u}$ & 1 & 1 & 3 & 2 & $\mathrm{E}$ \\
\hline Sisymbrium loeselii & Brassicaceae & $\mathrm{u}$ & 1 & 2 & 3 & 4 & $\mathrm{C}$ \\
\hline Sisymbrium officinale & Brassicaceae & $\mathrm{u}$ & 2 & 2 & 3 & 4 & $\mathrm{C}$ \\
\hline Solanum luteum & Solanaceae & $\mathrm{t}$ & 2 & 1 & 2 & $3,4,5$ & $\mathrm{E}$ \\
\hline Solanum nigrum & Solanaceae & $\mathrm{t}$ & 2.33 & 2.25 & 1.86 & $1,2,3,4,5,6,7,8$ & C, E, N, S \\
\hline Solanum physalifolium * & Solanaceae & $\mathrm{t}$ & 3 & 3 & 1 & 5 & $\mathrm{~S}$ \\
\hline Solanum sarachoides $*$ & Solanaceae & $\mathrm{t}$ & 1 & 1 & 2 & 5 & $\mathrm{C}$ \\
\hline
\end{tabular}


Appendix 1. Continued.

\begin{tabular}{|c|c|c|c|c|c|c|c|}
\hline Species & Family & $\mathrm{LF}$ & SPR & WED & $\mathrm{CON}$ & Crop systems & Regions \\
\hline Solanum tuberosum * & Solanaceae & $\mathrm{g}$ & 2 & 3 & 1 & $2,4,5$ & $\mathrm{~N}$ \\
\hline Sonchus arvensis & Asteraceae & $\mathrm{h}$ & 2.31 & 2.08 & 1.54 & $1,2,3,4,5,6,7,8$ & $\mathrm{E}, \mathrm{N}, \mathrm{S}$ \\
\hline Sonchus asper & Asteraceae & $\mathrm{t}$ & 3 & 2 & 2 & 1 & $\mathrm{~N}$ \\
\hline Sonchus oleraceus & Asteraceae & $\mathrm{t}$ & 3 & 2.5 & 2 & $1,2,3,4,5,6,7$ & $\mathrm{E}, \mathrm{S}$ \\
\hline Sorghum bicolor * & Poaceae & $\mathrm{t}$ & 3 & 3 & 3 & 4 & $S$ \\
\hline Sorghum halepense * & Poaceae & $\mathrm{h}$ & 2.5 & 2.52 & 1.81 & $1,2,3,4,5,6,7$ & $C, E, S$ \\
\hline Sorghum nigrum * & Poaceae & $\mathrm{t}$ & 3 & 2 & 2 & $2,3,4,5$ & S \\
\hline Spergula arvensis & Caryophyllaceae & $\mathrm{t}$ & 1.5 & 2 & 2 & $2,3,4$ & $\mathrm{E}$ \\
\hline Stachys аппиа & Lamiaceae & $\mathrm{t}$ & 2 & 2 & 2 & $1,2,3,4,5,6$ & $\mathrm{E}$ \\
\hline Stachys palustris & Lamiaceae & $\mathrm{g}$ & 2.5 & 2 & 1 & $2,3,4,5$ & $\mathrm{E}, \mathrm{N}$ \\
\hline Stellaria graminea & Caryophyllaceae & $\mathrm{h}$ & 2 & 2 & 2 & 2,3 & $\mathrm{E}$ \\
\hline Stellaria media & Caryophyllaceae & $\mathrm{t}$ & 2.17 & 2.39 & 2 & $1,2,3,4,5,6,7$ & $\mathrm{E}, \mathrm{N}, \mathrm{S}$ \\
\hline Symphytum officinale & Boraginaceae & $\mathrm{h}$ & 2 & 1.5 & 2 & $1,2,4,6$ & $\mathrm{C}, \mathrm{E}$ \\
\hline Tagetes minuta $*$ & Asteraceae & $\mathrm{t}$ & 2 & 2 & 2 & 7 & $\mathrm{C}$ \\
\hline Tanacetum vulgare & Asteraceae & $\mathrm{h}$ & 2 & 2 & 1 & $1,2,3,6,7,8$ & $\mathrm{E}$ \\
\hline Taraxacum officinale & Asteraceae & $\mathrm{h}$ & 2.4 & 2.3 & 1.3 & $1,2,3,5,6,7,8$ & $\mathrm{E}, \mathrm{N}, \mathrm{S}$ \\
\hline Thlaspi arvense & Brassicaceae & $\mathrm{u}$ & 2 & 2 & 3 & $1,2,3,4,5,6$ & $\mathrm{E}$ \\
\hline Torilis arvensis & Apiaceae & $\mathrm{t}$ & 3 & 2 & 1 & 6,7 & S \\
\hline Trifolium arvense & Fabaceae & $\mathrm{u}$ & 1 & 2 & 2 & 1,2 & $\mathrm{E}$ \\
\hline Tussilago farfara & Asteraceae & $\mathrm{g}$ & 1.5 & 2 & 1.5 & $1,2,4,6,7$ & $\mathrm{C}, \mathrm{S}$ \\
\hline Typha latifolia & Typhaceae & $\mathrm{g}$ & 2 & 1.5 & 1.5 & 1 & $\mathrm{E}$ \\
\hline Urtica dioica & Urticaceae & $\mathrm{h}$ & 3 & 2 & 2 & 6 & $\mathrm{C}$ \\
\hline Urtica urens & Urticaceae & $\mathrm{t}$ & 2.29 & 2.57 & 2.33 & $1,4,5,6,7$ & $C, E, S$ \\
\hline Veratrum album & Liliaceae & $\mathrm{h}$ & 2 & 3 & 1 & 1,6 & $\mathrm{E}$ \\
\hline Veronica hederifolia & Scrophulariaceae & $\mathrm{u}$ & 1 & 1 & 2 & 2 & $\mathrm{E}$ \\
\hline Veronica persica $*$ & Scrophulariaceae & $\mathrm{t}$ & 3 & 2.67 & 2.67 & $1,2,3,4,5,6,7$ & $\mathrm{E}, \mathrm{S}$ \\
\hline Vicia cracca & Fabaceae & $\mathrm{h}$ & 3 & 2 & 1 & 2,5 & $\mathrm{E}$ \\
\hline Vicia hirsuta & Fabaceae & $\mathrm{t}$ & 2 & 2.5 & 2 & $2,3,4,5,6,7$ & E \\
\hline Vicia villosa & Fabaceae & $\mathrm{u}$ & 3 & 3 & 1 & $2,6,7$ & $\mathrm{E}$ \\
\hline Viola arvensis & Violaceae & $\mathrm{u}$ & 2.22 & 2.22 & 1.78 & $2,3,4,5,6$ & $\mathrm{C}, \mathrm{E}, \mathrm{N}$ \\
\hline Viola tricolor & Violaceae & $\mathrm{u}$ & 1 & 2 & 2.5 & $1,2,4,5$ & $\mathrm{E}, \mathrm{S}$ \\
\hline Vulpia myuros & Poaceae & $\mathrm{t}$ & 2 & 2 & 2 & 2 & $S$ \\
\hline Vulpia unilateralis & Poaceae & $\mathrm{t}$ & 2 & 2 & 1 & 2 & S \\
\hline Xanthium italicum $*$ & Asteraceae & $\mathrm{t}$ & 3 & 2.5 & 1.8 & $1,2,3,4,5,6,7$ & $\mathrm{E}, \mathrm{S}$ \\
\hline Xanthium spinosum * & Asteraceae & $\mathrm{t}$ & 2 & 1.33 & 1.67 & $1,2,3,4,5$ & $\mathrm{E}, \mathrm{S}$ \\
\hline Xanthium strumarium & Asteraceae & $\mathrm{t}$ & 2.36 & 2.27 & 1.5 & $1,2,3,4,5,6$ & $\mathrm{E}, \mathrm{S}$ \\
\hline
\end{tabular}

$\mathrm{LF}=$ life form: a aquatic plant, $\mathrm{c}$ chamaephyte, $\mathrm{g}$ geophyte, $\mathrm{h}$ hemicryptophyte, $\mathrm{j}$ shrub, $\mathrm{n}$ small shrub, $\mathrm{p}$ vine, $\mathrm{u}$ biennial. $\mathrm{SPR}=$ mean score for spread potential ( 1 minimum, 3 maximum), WED = mean score for weediness $(1$ minimum, 3 maximum $), \mathrm{CON}=$ mean score for control success $(1$ minimum, e.g. difficult to control; 3 maximum, e.g. easy to control). CULT = number of culture systems in which species occurs. For definition of crop systems see text. * indicates that the species is alien to Europe. Crop systems refer to the systems for which species has been listed: 1 fodder plants and pastures, 2 cereals, 3 grain legumes, 4 root crops, 5 vegetables and ornamentals, 6 orchards, 7 vineyards, 8 other agricultural areas. Regions refers to the following regions in which the species has been listed: C Central Europe (Austria, France, Germany, The Netherlands), N Northern Europe (British Isles, Denmark, Finland, Norway, Sweden), E Eastern Europe (Bulgaria, Czech Republic, Hungary, Lithuania, Poland, Romania, Slovakia, Ukraine), S Southern Europe (Albania, Cyprus, Greece, Italy, Portugal, Spain, Turkey, Slovenia, Croatia). 